
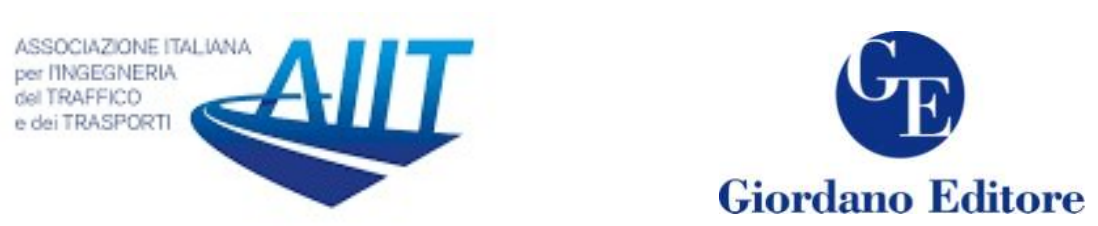

\author{
Giordano Editore
}

\title{
Economic assessment of pavement maintenance and strengthening techniques in view of implementation cost
}

\author{
Grigorios Papageorgiou ${ }^{1 *}$ \\ ${ }^{1}$ Assistant Professor of Road Engineering, University of Thessaly, Larissa, Greece
}

\begin{abstract}
Road and pavement maintenance affect directly traffic safety and comfort. At the same time, maintenance treatments cause traffic discomfort and absorb valuable resources, thus, the choice of maintenance and rehabilitation technique is a complex, yet crucial issue. Road operators need to seek for the financial prerequisites for the success of maintenance strategy. Subsequently, the expected economic benefits will be inextricably linked to road performance features. The study herewith presented enlightens the economic aspect of mainly used pavement maintenance techniques, so as road operators identify the preferred one as regards budget needs. A comprehensive method to evaluate the current maintenance and strengthening techniques for flexible pavements using economic assessment tools is the main task of this paper. The results are meant to be a useful tool for road operators to conclude to the preferable, in terms of financial needs, alternative for maintenance and strengthening works.
\end{abstract}

Keywords: Economic assessment, pavement, maintenance, strengthening, techniques, implementation cost.

\section{Introduction}

Road maintenance is a critical task concerning road managers. This is because the right maintenance strategy leads to the optimal exploitation of the road infrastructure in the scope of its life cycle. Especially nowadays, the rational management of resources in any construction activity stands for one of the main issues. The financial component is also one of the main selection criteria in every case of pavement treatment. Specifically, the reduction in construction cost is a crucial component of pavement maintenance and strengthening techniques. The choice of the most economical technique is very important for road authorities and manufacturers. Minimizing budget, benefits the project owner as well as the contractor. Thus, these saved resources can be used for other current or planned needs. In other words, the economic parameter of such works tends to be nowadays, a crucial factor in decision making procedures. The mitigation of operations

\footnotetext{
* Corresponding author: Grigorios Papageorgiou (gpapageor@uth.gr)
} 
cost is, along with implementation quality and precision in application, of utmost importance for operators as well as for road authorities. Less expenses means more fiscal field for improved maintenance strategies over time.

Pavement maintenance is undoubtedly an essential action for roadways management. While the main concern of relative studies is the selection method for the optimum maintenance strategy, namely preventive / routine maintenance, rehabilitation or reconstruction, there is lack of studies that address the issue of maintenance and strengthening techniques' economic evaluation. The first attempt to evaluate these techniques based on engineering and economic criteria is the recent research by Mouratidis et al. (2019). Drawing on the detailed and interesting findings of this research, the present paper is focusing in evaluating the main pavement maintenance and strengthening techniques in view of implementation cost. The most economically advantageous treatment, in the frame of maintenance or strengthening operation, stands for the objective of this study.

With the implementation of the herein proposed method of economic evaluation, it is possible to find the optimal in terms of cost, technique of pavement maintenance or strengthening, depending on the life cycle of each alternative. The results of the presented evaluation demonstrate fruitful findings and the proposed method can serve as a tool for finding the most economical option depending on the prevailing conditions during the implementation of the project. The construction cost at the time of maintenance activity and the durability of each technique according to the specific traffic conditions of each case, stand for critical factors, which differentiate the recommended treatment, respectively.

\section{Pavement management influence and aspects}

Pavement stands for the cornerstone of road infrastructure. Its condition and especially its surface integrity reflect to the safety level the roadway offers to its users, meaning that reduced or inadequate maintenance, results in increase in accidents due to deterioration of safety assets (ERF, 2013). Pavement safety performance is proved to be correlated with surface or structural distresses according to numerous researches (Rizenbergs et al., 1972; Gothie, 1996; Wallman and Astrom, 2001; Viner et al., 2004; Davis et al., 2005; Highways Agency, 2007; Mayora and Pina, 2009; Chan et al., 2010; Liu and Tinkler, 2010; Fwa et al., 2012; Papageorgiou and Mouratidis, 2015), due to either insufficient maintenance or lack of necessary strengthening. Additionally, wider benefits, such as sustaining local businesses, tourism and agriculture, which are connected to the access levels, are affected by the overall road quality (World Road Association, 2014). In parallel, the pavement serviceability defines other important factors, such as ride comfort and travel time cost (Ihs and Leif, 2003; Odoki and Kerali, 2000), that, nowadays, stand for core features of modern road infrastructures.

In this frame, road authorities or governments are obliged to program and implement relative operations to maintain pavement condition up to adequate status. In parallel, a road asset management system is called to predict needs and identify methods suitable to maintain and upgrade road assets by taking into consideration available financial resources (Ibraheem and Gani, 2011). 
The level of pavement condition, depicted from various condition indices worldwide, composed of the above features, is a function varying with time. This change reflects the wear rate of the pavement and determines, in line with the general policy of road maintenance, the time limits in which these technical operations should be performed.

However, in many cases, road agencies do not opt for the rationally recommended technique while, in other, deferred maintenance for administrative or financing reasons makes the rule. In both cases, the road user expenses but also the operating costs increase dramatically (Figure 1).

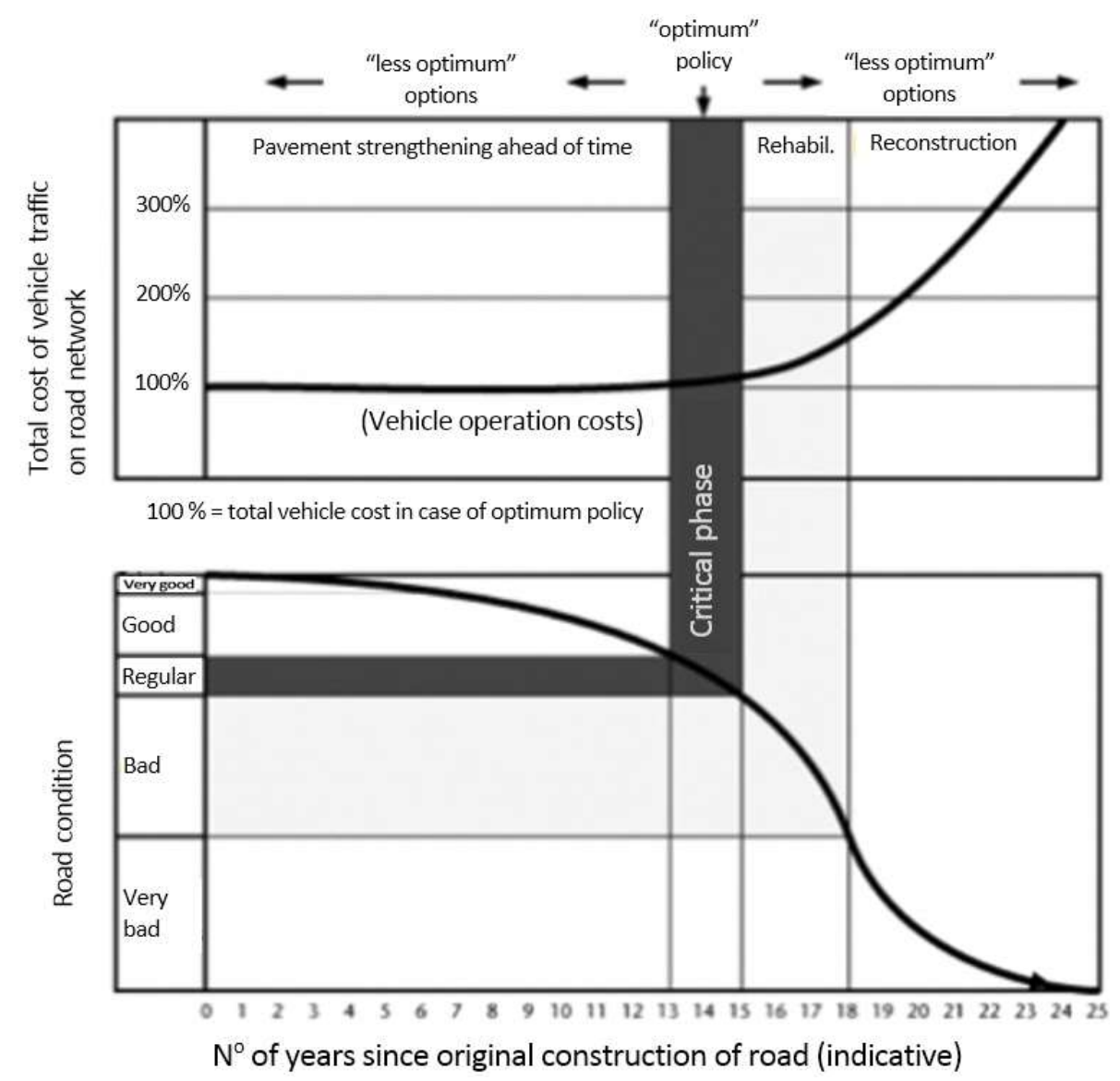

Figure 1: The variation of costs with time.

Source: World Bank, 2012.

The economic evaluation method herewith presented enlightens the economic aspect, namely implementation cost of each maintenance and strengthening technique so as to propose the best alternative in terms of financial needs at the construction stage.

\section{Overview of pavement maintenance evaluation methods}

Optimization of road asset management aims at three, quite distinct, targets: upgrade road serviceability, minimize construction and operating costs, cause minimum hindrance to road-users and neighbours. The best choice, in every case, of the technique to be applied may contribute decisively to this objective.

Previous research on maintenance evaluation techniques to optimize benefits can be found in relevant reports of worldwide literature. In some cases, the advantages and 
drawbacks of each technique are presented while, in other, some economic aspects of maintenance are outlined.

The FHWA Report (1996) on "Pavement Maintenance Effectiveness - Preventive Maintenance Treatments" presents in a comprehensive way, the most common maintenance techniques (materials, overlay thickness, equipment, field of application) as well as lessons learnt from previous experience.

The FHWA Report (2017) on "Pavement Performance Measures and Forecasting and the Effects of Maintenance and Rehabilitation Strategy on Treatment Effectiveness" presents a simple distress / possible cause / recommended operation matrix for maintenance and rehabilitation (strengthening). It also introduces the terms RFP (remaining functional period) and RSP (remaining structural period) and attempts a correlation of evolving defects with proper time for maintenance required.

In a PIARC report (2012), the challenge of reduction of construction time and cost of road pavements is presented as well as an overview of actions with beneficial effects: tendering procedures, selection of technical solutions, organization methods for the works.

The "Manifesto for long-term, effective management of a safe and efficient European road network" (ERF, 2013), emphasizes on the importance of timely and meticulous maintenance, indicating current rates of maintenance cost $(0.5 \%)$ with respect to the construction cost and respective optimum/required rates $(1.5 \%)$ to extend lifetime of the existing road infrastructure.

Putman et al. (2006), in a report on "Ranking of Pavement Preservation Practices and Methods", presented a comprehensive distress/maintenance technique matrix, as well as, a life-cycle analysis of cost for various maintenance techniques.

Zhou et al. (2013) evaluate maintenance technologies based on an "Economic-Benefit" index, and Luhr and Rydholm (2015) propose an "Economic Evaluation of Pavement Management Decisions" by monitoring cost-effectiveness by location and evaluating the cost-effectiveness of individual contracts.

Zuniga-Garcia et al. (2018) conducted an economic analysis of pavement preservation techniques, developing a life cycle cost assessment (LCCA) framework, comparing three primary pavement maintenance treatments used in Texas.

The evaluation method proposed herewith attempts an economic assessment of both, maintenance and strengthening techniques for road pavements. While operators and public authorities are fully aware of the construction cost of each technique, the durability of each one varies significantly. The highlight of this variation and its effect on the treatment cost are, in fact, the objectives of the proposed evaluation method, herewith presented.

\section{Economic assessment of maintenance and strengthening techniques}

\subsection{Selection of evaluation tool.}

While application cost of maintenance and strengthening techniques may be tempting in favour of the less costly ones, a crucial parameter in terms of economic evaluation is each one's durability in time. The more time-resistant alternatives could be appropriate for implementation regardless of relative higher cost. This is the prism, through which this paper examines the decision for the treatment to be applied. 
Such a comparative analysis, can be conducted in terms of net present value (NPV) or equivalent uniform annual cost (EUAC) as it is expressed in investment analysis theory and adopted by Luhr and Rydholm (2015) in the frames of cost-effectiveness analysis of pavement management decisions. Given the fact that NPV is expressed in terms of total cost for a specific time horizon, the comparison is difficult due to varying durability periods according to each treatment, meaning that multiple performance periods for treatments total time identification is necessary. On the contrary, EUAC presents in a better way the cost-effectiveness, as it is independent of the durability period and distributes cost on annual basis.

The conversion of application costs into equivalent uniform annual costs is achieved by the following formula:

$$
E U A C=C_{0} \frac{i(1+i)^{n}}{(1+i)^{n}-1}
$$

where

$\mathrm{C}_{0}=$ construction cost, $\mathrm{i}=$ discount rate, $\mathrm{n}=$ durability period in years

As EUAC relates cost to a certain period of time, it is preferable over NPV, that expresses only the total cost. Moreover, the EUAC is easier to calculate, since durability periods of compared treatments do not affect the reliability of the comparison (not the case of NPV).

\subsection{Economic evaluation.}

The construction cost consists of materials and implementation (equipment, labor) values. With regard to "construction cost", it refers to the cost of materials and laying (Putman et al. 2016; Cerea 2010; FHWA 1996). However, the total construction cost includes also preliminary treatment, markings, etc. The values included in Tables 1, 2, that refer to estimated current prices in Europe according to the recent extensive research by Mouratidis et al. (2019), were adopted in this study.

Table 1: Construction cost and durability of maintenance techniques.

\begin{tabular}{|c|c|c|}
\hline $\begin{array}{l}\text { Type of } \\
\text { asphalt overlay/ } \\
\text { technique }\end{array}$ & $\begin{array}{l}\text { Construction } \\
\text { cost }\end{array}$ & Durability \\
\hline $\begin{array}{l}\text { Thin HMA Overlay } \\
(2-3 \mathrm{~cm})\end{array}$ & $\begin{array}{l}\text { Very high } \\
\left(1.8-2.2 € / \mathrm{m}^{2}\right)\end{array}$ & $\begin{array}{l}\text { Excellent } \\
\text { (7-10 years) }\end{array}$ \\
\hline $\begin{array}{l}\text { Slurry seal (cold - } \\
\text { single layer) } \\
(0.5-1.5 \mathrm{~cm})\end{array}$ & $\begin{array}{l}\text { Fair } \\
\left(0.7-1.1 € / \mathrm{m}^{2}\right)\end{array}$ & $\begin{array}{l}\text { Fair } \\
\text { (3-5 years) }\end{array}$ \\
\hline $\begin{array}{l}\text { BBTM (hot) } \\
(2-3 \mathrm{~cm})\end{array}$ & $\begin{array}{l}\text { High } \\
\left(1.2-2.0 € / \mathrm{m}^{2}\right)\end{array}$ & $\begin{array}{l}\text { Very good } \\
(6-8 \text { years })\end{array}$ \\
\hline $\begin{array}{l}\text { Surface dressing } \\
\text { (single) } \\
(0.5-1.5 \mathrm{~cm})\end{array}$ & $\begin{array}{l}\text { Fair } \\
\left(0.8-1.2 € / \mathrm{m}^{2}\right)\end{array}$ & $\begin{array}{l}\text { Fair } \\
\text { (3-5 years) }\end{array}$ \\
\hline $\begin{array}{l}\text { Microsurfacing (cold) } \\
(1-1.5 \mathrm{~cm}) \\
\text { Local Repair (fog seal, } \\
\text { crack sealing) }\end{array}$ & $\begin{array}{l}\text { High } \\
\left(1.1-1.6 € / \mathrm{m}^{2}\right) \\
\text { Very low } \\
\left(0.3-0.5 € / \mathrm{m}^{2}\right)\end{array}$ & $\begin{array}{l}\text { Good } \\
\text { (5-7 years) } \\
\text { Fair } \\
\text { (2-6 years) }\end{array}$ \\
\hline
\end{tabular}

Source: Mouratidis et al., 2019. 
Table 2: Construction cost and durability of strengthening techniques.

\begin{tabular}{|c|c|c|}
\hline $\begin{array}{l}\text { Type of } \\
\text { asphalt overlay / } \\
\text { technique }\end{array}$ & $\begin{array}{l}\text { Construction } \\
\text { cost }\end{array}$ & Durability \\
\hline $\begin{array}{l}\text { HMA Overlay } \\
(5-8 \mathrm{~cm})\end{array}$ & $\begin{array}{l}\text { Very low } \\
\left(5-8 € / \mathrm{m}^{2}\right)\end{array}$ & $\begin{array}{l}\text { Excellent } \\
\text { (10-15 years) }\end{array}$ \\
\hline $\begin{array}{l}\text { Hot Rolled asphalt } \\
(4-6 \mathrm{~cm})\end{array}$ & $\begin{array}{l}\text { Fair } \\
\left(10-15 € / \mathrm{m}^{2}\right)\end{array}$ & $\begin{array}{l}\text { Excellent } \\
\text { (10-15 years) }\end{array}$ \\
\hline $\begin{array}{l}\text { Stone Matrix Asphalt } \\
(6-8 \mathrm{~cm})\end{array}$ & $\begin{array}{l}\text { Low } \\
\left(6-10 € / \mathrm{m}^{2}\right)\end{array}$ & $\begin{array}{l}\text { Good } \\
\text { (8-12 years) }\end{array}$ \\
\hline $\begin{array}{l}\text { Recycling without } \\
\text { overlay } \\
(5-8 \mathrm{~cm})\end{array}$ & $\begin{array}{l}\text { Fair } \\
\left(9-10 € / \mathrm{m}^{2}\right)\end{array}$ & $\begin{array}{l}\text { Fair } \\
\text { (4-8 years) }\end{array}$ \\
\hline $\begin{array}{l}\text { Overlays with fiber } \\
\text { reinforcement } \\
(4-6 \mathrm{~cm})\end{array}$ & $\begin{array}{l}\text { High } \\
\left(15-22 € / \mathrm{m}^{2}\right)\end{array}$ & $\begin{array}{l}\text { Very good } \\
(10-13 \text { years })\end{array}$ \\
\hline $\begin{array}{l}\text { Glasgrid + Overlay } \\
(2.5-5 \mathrm{~cm})\end{array}$ & $\begin{array}{l}\text { Very high } \\
\left(18-22 € / \mathrm{m}^{2}\right)\end{array}$ & $\begin{array}{l}\text { Very good } \\
\text { (10-12 years) }\end{array}$ \\
\hline
\end{tabular}

Source: Mouratidis et al., 2019.

Preventive maintenance and strengthening techniques for road pavements are comparatively evaluated in Tables 1 and 2, accordingly, considering construction cost and durability period of each treatment. Recycling and glasgrid reinforced overlay (FHWA 2004; Nguyen et al. 2013), are indicated in case of geometric limitations of pavement elevation, prohibitive for thick overlays.

Assuming discount rate of $4 \%$, the calculation of mean EUAC, namely EUAC of the mean values of construction cost and durability from Tables 1 and 2, using the mathematical formula (1), results in values as shown in Tables 3 and 4, for maintenance and strengthening techniques, accordingly.

Although mean values of EUAC point out relative hierarchy of cost-effectiveness, the variation of EUAC values according to the initial construction cost and the estimated durability period, leads to subsequent change in alternatives' ranking. Thus, a sensitivity analysis for certain potential cases should be considered.

Table 3: Mean EUAC of maintenance techniques.

\begin{tabular}{lc}
\hline $\begin{array}{l}\text { Type of } \\
\text { asphalt overlay / } \\
\text { technique }\end{array}$ & $\begin{array}{c}\text { EUAC }\left(€ / \mathrm{m}^{2}\right) \\
\text { per year }\end{array}$ \\
\hline $\begin{array}{l}\text { Thin HMA Overlay } \\
\text { Slurry seal (cold - }\end{array}$ & 0.282 \\
$\begin{array}{l}\text { single layer) } \\
\text { BBTM (hot) }\end{array}$ & 0.248 \\
$\begin{array}{l}\text { Surface dressing } \\
\text { (single) }\end{array}$ & 0.267 \\
$\begin{array}{l}\text { Microsurfacing (cold) } \\
\text { Local Repair (fog seal, } \\
\text { crack sealing) }\end{array}$ & 0.275 \\
\hline
\end{tabular}


Table 4: Mean EUAC of strengthening techniques.

\begin{tabular}{lc}
\hline $\begin{array}{l}\text { Type of } \\
\text { asphalt overlay / } \\
\text { technique }\end{array}$ & $\begin{array}{c}E U A C\left(\epsilon / \mathrm{m}^{2}\right) \\
\text { per year }\end{array}$ \\
\hline HMA Overlay & 0.671 \\
Hot Rolled asphalt & 1.290 \\
Stone Matrix Asphalt & 0.986 \\
Recycling & 1.812 \\
Overlays with fiber & 2.038 \\
reinforcement & 2.283 \\
Glasgrid + Overlay & \\
\hline
\end{tabular}

Figures 2 and 3 show the differences in EUAC values for certain construction cost durability periods combinations, as following:

- minimum construction cost - maximum durability period (EUAC-dl)

- minimum construction cost - minimum durability period (EUAC-ul)

- mean construction cost - mean durability period (EUAC-m)

- maximum construction cost - maximum durability period (EUAC-dr)

- maximum construction cost - minimum durability period (EUAC-ur)

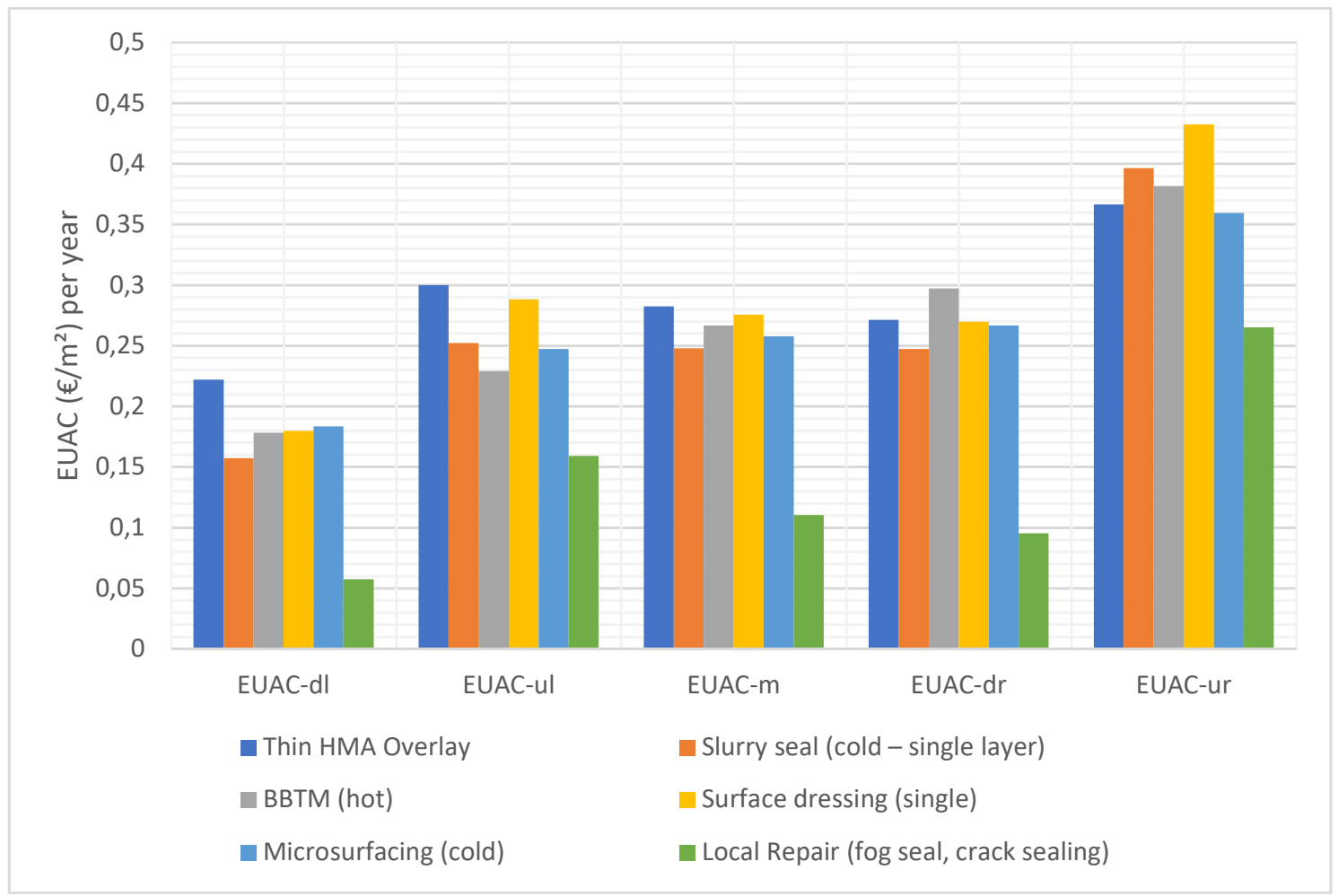

Figure 2: EUAC of pavement maintenance techniques according to initial construction cost and durability. 


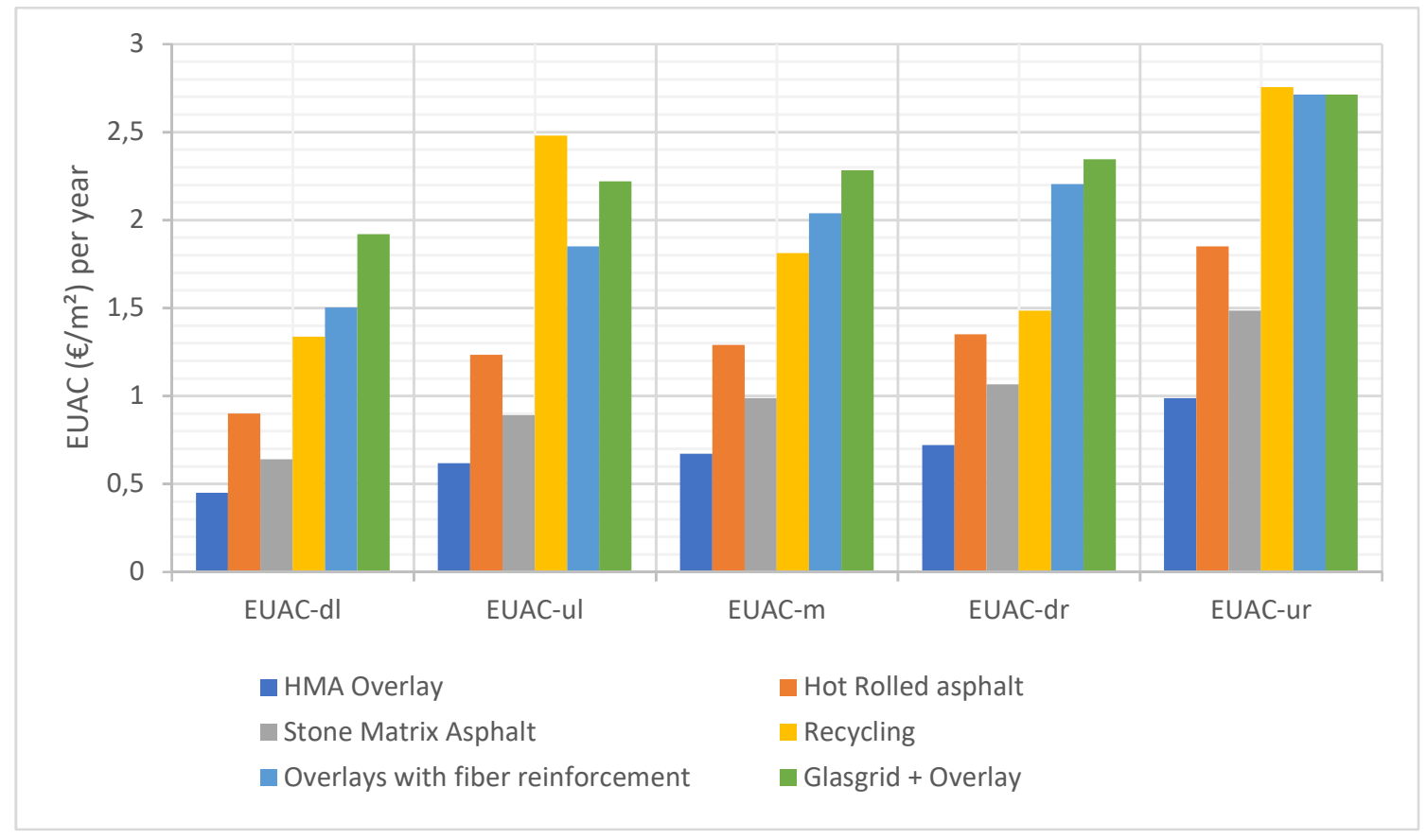

Figure 3: EUAC of pavement strengthening techniques according to initial construction cost and durability.

Ranking of alternative options with respect to EUAC values (rank number 1 assigned to the less costly treatment and number 5 to the most expensive one), are shown in Tables 5 and 6.

Derived from the findings of Tables 5 and 6, Local Repair stands for the most costeffective alternative as regards the application cost, yet is applicable only in cases of localized and limited surface area distresses. Regarding more extended wear, Local Repair is excluded from consideration, and the proposed most cost-effective treatment varies according to initial construction cost pricing and estimated durability period of application. Combined engineering consideration of traffic features (traffic volume, percentage of heavy vehicles) along with current financial environment (materials and use of equipment-labor costs), defines the EUAC value used to conduct the economic evaluation. For example, in case of minimum materials and equipment costs along with maximum durability period projection, the comparison should be conducted on the basis of EUAC-dl.

Table 5: Ranking of pavement maintenance techniques with respect to EUAC.

\begin{tabular}{|c|c|c|c|c|c|}
\hline $\begin{array}{l}\text { Type of } \\
\text { asphalt overlay/ } \\
\text { technique }\end{array}$ & $E U A C-d l$ & $E U A C-u l$ & $E U A C-m$ & $E U A C-d r$ & $E U A C-u r$ \\
\hline Thin HMA Overlay & 6 & 6 & 6 & 5 & 3 \\
\hline $\begin{array}{l}\text { Slurry seal } \\
\text { (cold - single layer) }\end{array}$ & 2 & 4 & 2 & 2 & 5 \\
\hline BBTM (hot) & 3 & 2 & 4 & 6 & 4 \\
\hline $\begin{array}{l}\text { Surface dressing } \\
\text { (single) }\end{array}$ & 4 & 5 & 5 & 4 & 6 \\
\hline Microsurfacing (cold) & 5 & 3 & 3 & 3 & 2 \\
\hline $\begin{array}{l}\text { Local Repair } \\
\text { (fog seal, crack sealing) }\end{array}$ & 1 & 1 & 1 & 1 & 1 \\
\hline
\end{tabular}


Table 6: Ranking of pavement strengthening techniques with respect to EUAC.

\begin{tabular}{lccccc}
\hline $\begin{array}{l}\text { Type of } \\
\text { asphalt overlay/ } \\
\text { technique }\end{array}$ & EUAC-dl & EUAC-ul & EUAC-m & EUAC-dr & EUAC-ur \\
\hline HMA Overlay & 1 & 1 & 1 & 1 & 1 \\
Hot Rolled asphalt & 3 & 3 & 3 & 3 & 3 \\
Stone Matrix Asphalt & 2 & 2 & 2 & 2 & 2 \\
Recycling & 4 & 6 & 4 & 4 & 5 \\
$\begin{array}{l}\text { Overlays with fiber } \\
\text { reinforcement }\end{array}$ & 5 & 4 & 5 & 5 & 4 \\
Glasgrid + Overlay & 6 & 5 & 6 & 6 & 4 \\
\hline
\end{tabular}

\subsection{Implementation example.}

In order to assess the results of the above proposed evaluation comprehensively, an implementation example is examined. The case study was considered for a two-lane road with a $3.5 \mathrm{~m}$ width per lane that presents extensive surface distresses, namely small cracks and slipperiness. The length of the road segment is $10 \mathrm{~km}$. Equipment and personnel are experienced in such maintenance operations and the durability period of the application is considered as the minimum estimated due to high traffic volume with high percentage of heavy vehicles as well. The application cost is considered the maximum due to high materials cost at the time the operations take place. Given the above, the EUAC-ur of the alternatives except for Local Repair, are set in comparison.

Firstly, given the fact that distresses are observed on extensive surface, the alternative of Local Repair is excluded from evaluation. The other five alternatives, namely: a) Thin HMA overlay, b) Slurry Seal, c) BBTM, d) Surface Dressing, and e) Microsurfacing, are evaluated in terms of EUAC-ur.

Results of this evaluation and corresponding ranking are shown in Table 7. After the implementation of the proposed methodology, the optimal in terms of application cost, in the case examined, is Microsurfacing, the Thin HMA Overlay comes second, and the last one is Surface dressing.

Table 7: EUAC-ur values and subsequent ranking for the implementation example.

\begin{tabular}{lccc}
\hline $\begin{array}{l}\text { Type of } \\
\text { asphalt overlay/ } \\
\text { technique }\end{array}$ & $\begin{array}{c}\text { EUAC-ur } \\
(€ \text { per year) }\end{array}$ & $\begin{array}{c}\text { EUAC difference } \\
\text { from optimum } \\
\text { (€ per year) }\end{array}$ & Ranking \\
\hline $\begin{array}{l}\text { Thin HMA Overlay } \\
\text { Slurry seal }\end{array}$ & 25,658 & 500 & 2 \\
(cold - single layer) & 27,747 & 2,589 & 4 \\
$\begin{array}{l}\text { BBTM (hot) } \\
\begin{array}{l}\text { Surface dressing } \\
\text { (single) }\end{array}\end{array}$ & 26,707 & 1,548 & 3 \\
$\begin{array}{l}\text { Microsurfacing } \\
\text { (cold) }\end{array}$ & 30,269 & 5,111 & 5 \\
\hline
\end{tabular}

\section{Conclusions}

While various techniques for pavement maintenance and strengthening are applicable, each one of them presents unique range of construction cost depending on the current 
price levels of materials and labor, equipment costs, as well as specific range of estimated durability period depending on the traffic characteristics of the road. These ranges, directly define the EUAC of each treatment option for the pavement examined. Thus, comparison of alternatives through EUAC values stands for a comprehensive method to conclude to the preferable method in terms of implementation financial needs.

In general, the findings of the proposed evaluation method, indicate that the most costeffective of the available treatments, proves to differ according to the combination of construction cost - durability period that occurs in each case.

Especially regarding the strengthening treatments, HMA Overlay proves to be the most cost-effective one, with Stone Matrix Asphalt and Hot Rolled Asphalt to follow in the ranking, regardless of the variation of construction cost - durability period combination.

The proposed method supplies road authorities and operators with a useful tool to evaluate and rank pavement maintenance or strengthening alternative techniques in economic terms. In this way, they are able to manage their budget resources adequately and whenever is considered required, to select the appropriate maintenance or strengthening technique in terms of economic benefits.

Future research on this field, consists of comparative analysis of other economic components of pavement treatments, such as maintenance management cost, cost at operational stage, toll fee revenues and societal/road user benefits.

\section{References}

Cerea, P. (2010) Preventive Maintenance Treatments on Road Pavements: MultiApproach Life-Cycle Assessment, Graduation Thesis, Politecnico di Milano, Italy.

Chan, Y.C., Huang, B., Yan, X., Richards, S. (2008) "Effects of Asphalt Pavement Conditions on Traffic Accidents in Tennessee Utilizing Pavement Management System (PMS)". Southeastern Transportation Center. University of Tennessee, Knoxville. USA.

Chan, Y.C., Huang, B., Yan, X., Richards, S. (2010) "Investigating effects of asphalt pavement conditions on traffic accidents in Tennessee based on the pavement management system (PMS)", Journal of Advanced Transportation, 44, pp. 150-161.

Davis, R.B., Cenek, P.D., Henderson, R.J. (2005) "The effect of skid resistance and texture on crash risk", Proceedings of the International Surface Friction Conference, Christchurch, New Zealand, 1-4 May 2005.

European Road Federation (ERF) (2013) “A Manifesto on Road Asset Management (RAM) 'Keeping Europe Moving - A Manifesto for long-term, effective management of a safe and efficient European road network",, Brussels.

Federal Highway Administration (FHWA) (1996) "Pavement Maintenance Effectiveness - Preventive Maintenance Treatments", Prepared by Center for Advanced Transportation Systems Research. Arizona State University, Publication No. FHWASA-96-028, VA, USA.

Federal Highway Administration (FHWA) (2004) "Performance Report on Jointed Concrete Pavement Repair Strategies in Texas", Performed in cooperation with the Texas Department of Transportation and the Federal Highway Administration, Publication No. FHWA/TX-05/0-4517-1, VA, USA. 
Federal Highway Administration (FHWA) (2017) "Pavement Performance Measures and Forecasting and the Effects of Maintenance and Rehabilitation Strategy on Treatment Effectiveness (Revised)", Publication No. FHWA-HRT-17-095, VA, USA.

Fwa, T.F., Pasindu, H.R., Ong, G.P. (2012) "Critical Rut Depth for Pavement Maintenance Based on Vehicle Skidding and Hydroplaning Consideration", Journal of Transportation Engineering, 138 (4), pp. 423-429.

Gothie, M. (1996) "Relationship between Surface Characteristics and Accidents", Proc. $3^{\text {rd }}$ International Symposium on Pavement Surface Characteristics, pp. 271-281.

Highways Agency (HA) (2007) "Guidance for HA Service Providers on Implementing the Skid Resistance Policy (HD28/04)”, Interim Advice Note 98/07, September 2007, UK.

Ibraheem, A.T., Gani, S.M. (2011) "Evaluation of Common Maintenance Methods for Flexible Pavements", Am. J. Eng. Applied Sci., 4, pp. 413-424.

Ihs, Anita, Leif, Sjőgren (2003) "An Overview of HDM-4 and the Swedish Pavement Management System (PMS), VTI (Swedish National Road and Transport Research Institute).

Liu, W., Tinkler, B. (2010) "Variable Slip Skid Resistance Testing for Road Safety Investigation and Pavement Management", ASCE Conf. Proc., doi: http://dx.doi.org/10.1061/41104(377)56, Paving Materials and Pavement Analysis (GSP 203), Proceedings of the 2010 GeoShanghai International Conference.

Luhr, D.R., Rydholm, T.C. (2015) "Economic Evaluation of Pavement Management Decisions", $9^{\text {th }}$ International Conference on Managing Pavement Assets, Alexandria, VA, USA.

Mayora, J.M., Pina, R.J. (2009) "An assessment of the skid resistance effect on traffic safety under wet-pavement conditions", Accident Analysis and Prevention, Elsevier, 41, pp. 881-886.

Mouratidis, A., Daniilidou, C.G., Papageorgiou, G.P. (2019) "Evaluation of pavement mainte-nance and strengthening techniques", Proc. 7th International Conference "Bituminous Mixtures and Pavements", 12-14 June 2019, Thessaloniki, Greece.

Nguyen, M.L., Blanc, J., Kerzrého, J.P., Hornych, P. (2013) "Review of glass fibre grid use for pavement reinforcement and APT experiments at IFSTTAR", Road Materials and Pavement Design, Editions Hermes, 14 (Supplement 1), pp.287-308.

Odoki, J.B., Kerali, H.G.R. (2000) "HDM-4 analytical framework and model descriptions", Vol. 4, highway development and management, HDM-4 series of publications, World Bank, Washington DC, \& PIARC, Paris, France.

Papageorgiou G., Mouratidis, A. (2015) "Defining Threshold Values for Pavement Surface Characteristics", Proceedings of the Institution of Civil Engineers - Transport, ICE Publishing, Thomas Telford, London, United Kingdom, 168 (3), pp. 223 -230.

Putman, B.J., Ogle, J.H., Huang, Y., Reed, L. (2006) "Ranking of Pavement Preservation Practices and Methods", Report No. FHWA-SC-16-05, Clemson University, South Carolina, USA.

Rizenbergs, R.L., Burchett, J.L., Napier, C.T. (1972) "Skid Resistance of Pavements", Report No. KYHPR-64-24, Part II, Kentucky Department of Highways, Lexington, Kentucky.

Viner, H., Sinhal, R., Parry, T. (2004) "Review of UK Skid Resistance Policy", Paper prepared for $5^{\text {th }}$ International Symposium on Pavement Surface Characteristics---Road and Airports, Toronto, Ontario, Canada. 
Wallman, C.G., Aström, H. (2001) "Friction Measurement Methods and the Correlation between Road Friction and Traffic Safety - Literature Review", Project Code 80435, Swedish National Road and Transport Research Institute, Linköping, Sweden.

World Bank (2012) "It's unwise to pay too much, but it's foolish to spend too little": Sustainable road sector development through asset management in the Kyrgyz Republic, World Bank, Washington, USA.

World Road Association (PIARC) (2012) "Reduction of construction time and cost of road pavements", La Défense, France.

World Road Association. (PIARC) (2014) “The importance of road maintenance", La Défense, France.

Zhou, B., Zhang, C., Tsai, J., Guo, X., Zhou, X. (2013) “Asphalt Pavement Maintenance Technologies Evaluation Model based on "Economic-Benefit" index", Procedia Social and Behavioral Sciences, 96, pp. 2115-2122.

Zuniga-Garcia, N., Martinez-Alonso, W., Smit, A., Hong, F., Prozzi, J.A. (2018) "Economic Analysis of Pavement Preservation Techniques", Transportation Research Record, DOI: 10.1177/0361198118768515. 